\title{
The Relationship between Managerial Satisfaction and Job Turnover Intention: The Mediating Role of Job Satisfaction
}

\author{
RÜVEYDA ÖZTÜRK BAŞOL \\ Kirklareli University, Turkey \\ ruveyda.ozturk@klu.edu.tr \\ HARUN DEMIRKAYA \\ Kocaeli University, Turkey \\ harundemirkaya@hotmail.com
}

\begin{abstract}
The growth of service sector in Turkey occurs faster than the other sectors and the number of shopping malls increases correspondingly. The rapid growth of the number of shopping malls has necessitated the measurement of the attitudes of the employees in this sector. This study demonstrated that the gender, marital status and age were not the significant variables on job satisfaction, managerial satisfaction and job turnover intention; however, education status and income status were found to be significant variables on job satisfaction and job turnover intention. In addition, job satisfaction fully mediated the relationship between managerial satisfaction and job turnover intention.
\end{abstract}

Key words: job satisfaction, managerial satisfaction, job turnover intention, smartPLS https://doi.org/10.26493/1854-4231.12.235-248

\section{Introduction}

The fact that the individuals of $\mathrm{Y}$ generation currently participate much more in work life makes the managers feel much responsibility on some particular areas. Some of the researches claim that the individuals quit their managers, not their jobs (Duffy et al. 2006; Stajkovic and Luthans 1998; McNatt and Judge 2008). On the other hand, it is possible to say that the number of shopping malls in Turkey is increasing significantly. In the year 1996, the number of shopping malls was 11, however in 2006 the number has reached up over 200 (Asiltürk 2010), and in 2016, this number was reported to be 361 (see http://www.ayd.org.tr/TR/DataBank.aspx). In other words, the increase in the number of shopping malls in Turkey is 35 times more 
than the latest 20 years. Thus, this enormous increase has necessitated the measurement of the perceptions about work/job attitudes of the individuals working in shopping malls.

Upon a research (dated 9 June 2016) on master and $\mathrm{PhD}$ theses (see https://tez.yok.gov.tr/UlusalTezMerkezi/tarama.jsp) and journals (see http://uvt.ulakbim.gov.tr) in social sciences field in Turkey, it is resulted that only three $\mathrm{PhD}$ theses, four master theses and six articles include 'shopping mall/center' title. Among these studies, it is seen that only one of them focused on the job satisfaction of employees working in shopping malls. Consequently, it can be stated that there seems to be only one study measuring the job perceptions of shopping mall employees in the Turkish academic literature.

The present study has three different goals. The first one is to determine if the demographic characteristics of shopping mall employees are significant on job satisfaction, managerial satisfaction and job turnover intention. The second one is to test if there is a significant relation between the variables i.e., job satisfaction, managerial satisfaction and job turnover intention. The third one is to investigate whether the job satisfaction of shopping mall employees mediate the relationship between managerial satisfaction and job turnover intention.

\section{Literature Review}

JOB SATISFACTION

Job satisfaction, as the most-used definition, is 'a pleasurable or positive emotional state resulting from the appraisal of one's job or job experiences' (Locke 1976). In other words, it is the individual's pleasure and happiness gained by work life (Keser 2011). The conventional job satisfaction models put forward that pay, nature of work, operating conditions, coworkers and supervision are the determiners in job satisfaction (Keser 2006). In addition, more modern approaches set forth that promotion, fringe benefits, contingent rewards and communication are also the subscales of job satisfaction (Spector 1985; 1997; Friday and Friday 2003).

Regarding the aforementioned job satisfaction factors, employees who are sufficiently satisfied with these determiners are evaluated as individuals that enjoy their jobs, behave positively and are successful in work life and private life, by being more committed to permanent improvement and quality (Dülgeroğlu and Taşkın 2015); on the contrary, the unsatisfied employees in the context are considered as the ones who have negative feelings, intend to quit job, remain in-

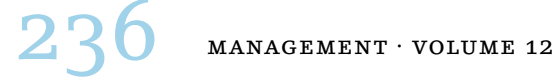


TABLE 1 Previous Researches in Turkey for Shopping Malls

\begin{tabular}{|c|c|}
\hline Type of research & Title of research. \\
\hline PhD thesis & $\begin{array}{l}\text { Impacts of shopping centres on consumption culture and } \\
\text { Turkey sample. }\end{array}$ \\
\hline PhD thesis & $\begin{array}{l}\text { Quality perception in service marketing: As an example of } \\
\text { Malatyapark. }\end{array}$ \\
\hline PhD thesis & $\begin{array}{l}\text { Effect of in store atmosphere in malls on consumption emo- } \\
\text { tions and buying behaviour. }\end{array}$ \\
\hline Master thesis & $\begin{array}{l}\text { The importance of the shopping center management for the } \\
\text { preferences of the shopping center by the consumers. }\end{array}$ \\
\hline Master thesis & $\begin{array}{l}\text { Investigation of reasons for preference shopping centres and } \\
\text { outlets and practice case. }\end{array}$ \\
\hline Master thesis & $\begin{array}{l}\text { The role of credit card misuse in the relationship between } \\
\text { compulsive buying tendency and post purchase regret: A } \\
\text { study on the shopping mall consumers. }\end{array}$ \\
\hline Master thesis & $\begin{array}{l}\text { The image of shopping centres, and an application on shop- } \\
\text { ping centres in Ankara. }\end{array}$ \\
\hline Research article & $\begin{array}{l}\text { The relationship of job satisfaction and life satisfaction be- } \\
\text { tween the demographic features: Research on employees of } \\
\text { the shopping center in Sakarya. }\end{array}$ \\
\hline Research article & $\begin{array}{l}\text { Youth and shopping malls: A case study about youth prefer- } \\
\text { ence in mall use. }\end{array}$ \\
\hline Research article & $\begin{array}{l}\text { Determination of female consumers' shopping mall choices } \\
\text { and a pilot research. }\end{array}$ \\
\hline Research article & $\begin{array}{l}\text { A comparison of shopping malls and street stores as regard to } \\
\text { choice of store location: A research in city of Ankara. }\end{array}$ \\
\hline Research article & $\begin{array}{l}\text { A research on the impact of shopping malls to the city life and } \\
\text { downtown retail shops in Salihli. }\end{array}$ \\
\hline Research article & $\begin{array}{l}\text { A comparative investigation on shopping mall perception of } \\
\text { consumers the case of 'lake area.' }\end{array}$ \\
\hline
\end{tabular}

Notes Adapted from Council of Higher Education (2016) and Social Science Database Turkey (2016).

different to job and have desperate thoughts for the future of their jobs (Tett and Meyer 1993).

\section{MANAGERIAL SATISFACTION}

The relation between employees and managers is a crucial factor in the happiness and satisfaction of the employees at work. Also, it is important that the managers can be able to communicate with their employees. If managers find it hard to communicate or make a dialog with their employees, it may be difficult for them to understand their employees, so, employees can also feel difficulty to understand their managers mutually. When managers reach their 
employees and behave equally and fairly towards them, these attitudes and behaviours can increase the job satisfaction of the employees (Keser 2011). In the literature, it is examined that positive managerial attitudes increase employees' job satisfaction (Ellinger and Bostrom 1999; Noelker et al. 2009; Başol 2016).

н1 Higher managerial satisfaction increases job satisfaction of employees.

\section{JOB TURNOVER INTENTION}

In the literature, concerning the concept of job turnover, which is the most important result of employees' dissatisfaction, many studies have shown that 'dissatisfied employees are more likely to quit their jobs or be absent than satisfied employees' (Brown and Peterson 1993; Crampton and Wagner 1994; Hanisch, Hulin, and Roznowski 1998; Karatuna and Başol 2017). The satisfaction level of employees is a crucial factor on quitting their job. High job satisfaction does not keep turnover low, however, it is likely to help. Besides, if there is remarkable job dissatisfaction, it is possible to be high turnover (Luthans 2011). It is known that the intention of leaving job is low for the employees who are highly satisfied at work (Truckenbrodt 2000; Lambert, Hogan, and Barton 2001). In addition, the organization's intention to keep the satisfied employees on their current jobs is much higher in comparison to the dissatisfied employees (Silah 2005). At the same time, in the workplaces where the employees' satisfaction is low, it might be stated that job switching and job turnover intention are high. When the relation between managerial satisfaction and job turnover intention is examined, it is resulted that there is a significant and strong relation between these two factors (Khatri, Budhwar, and Fern 1999; Rhoades and Eisenberger 2002; Maertz et al. 2007; Alkahtani 2015). Thus, we put forward the following hypotheses.

н2 Higher job satisfaction decreases job turnover intention of employees.

н3 Higher managerial satisfaction decreases job turnover intention of employees.

$\mathrm{H} 4$ Job satisfaction is the mediator of the relation between managerial satisfaction and job turnover intention.

\section{Method}

SAMPLE

Among 361 shopping malls in Turkey, only 3 of them locate in Kirklareli, Turkey (see http://www.ayd.org.tr/TR/DataBank.aspx). The 
TABLE 2 Demographic Characteristics of Shopping Mall Employees

\begin{tabular}{llrr}
\hline Demographics & & Frequency & Ratio \\
\hline Gender & Female & 78 & 48.4 \\
& Male & 83 & 51.6 \\
\hline Educational Status & Primary school & 36 & 22.4 \\
& High school & 56 & 34.8 \\
& BA & 59 & 36.6 \\
& MA or PhD & 10 & 6.2 \\
\hline Marital Status & Married & 67 & 41.6 \\
& Single & 94 & 58.4 \\
\hline Age & 20-30 & 96 & 59.6 \\
& 31-40 & 65 & 40.4 \\
\hline Net monthly income & O-1.300 TL & 42 & 26.1 \\
& 1.301 TL-2.60o TL & 88 & 54.7 \\
& 2.601 TL or more & 31 & 19.2 \\
\hline Total & & 161 & 100 \\
\hline
\end{tabular}

Notes Minimum wage in Turkey is $1.300 \mathrm{TL}=390$ Euro $=436$ Dollar.

sample of the survey was selected from shopping mall employees from Kirklareli city. In order to decide the target population, several meetings were made with shopping mall managers and it was detected that there were 406 employees in these shopping malls. It was determined that 198 samples would represent the target population (see http://www.surveysystem.com/sscalc.htm).

In table 2, the demographic characteristics of the participants are shown. Accordingly, $48.4 \%$ of the participants were female and $51.6 \%$ were male. Concerning the educational status, $22.4 \%$ of the participants graduated from primary school, $34.8 \%$ graduated from high school, $36.6 \%$ had BA level and $6.2 \%$ had MA or PhD level. $41.6 \%$ of the participants were married and $58.4 \%$ were single. The $59.6 \%$ of the participants were between $20-30$ years old and $40.4 \%$ were between 31-40 years old. Regarding the net monthly income of the participants, $26.1 \%$ of them had a minimum wage, $54.7 \%$ of them had a wage between $1.301 \mathrm{TL}-2.600 \mathrm{TL}$, and $19.2 \%$ of them had a wage over $2.601 \mathrm{TL}$.

\section{SURVEY FORM OF THE RESEARCH}

The survey consists of two parts. The first part includes 5 questions, seeking for information on the demographic characteristics (gender, educational status, marital status, age and net monthly income) of the participants. In the second part, the job satisfaction, managerial satisfaction and job turnover intentions of the participants were measured. 
- Job Satisfaction Scale: In order to measure the job satisfaction of the participants, Likert scale (1: I totally disagree; 5: I totally agree), developed by Brayfield and Rothe (1951) and including 5 items such as 'I like my job,' was used.

- Managerial Satisfaction Scale: In order to measure the managerial satisfaction of the participants, Likert scale (1: I totally disagree; 5: I totally agree), developed by Spector (1985) and including 4 items such as 'My manager is fair towards me,' was used.

- Job Turnover Intention Scale: In order to measure the job turnover intention of the participants, Likert scale (1: I totally disagree; 5: I totally agree), developed by Cammann, Jenkins, and Klesh (1979) and including 3 items such as 'I often think of quitting my job,' was used.

In order to determine the analyses for the variables, KolmogorovSmirnov normal distribution test was conducted; it was resulted that job satisfaction $(Z=2.118, p=0.00)$, managerial satisfaction $(Z=$ $2.346, p=0.00)$ and job turnover intention $(Z=2.889, p=0.00)$ variables were not distributed normally. Therefore, in order to test the differences $\mathrm{MW}-\mathrm{U}$ and $\mathrm{KW}-\mathrm{H}$ tests were computed. To test the relations between study variables, Spearman correlation test was used. In order to examine the hypothesis regarding the mediation effect, bootstrapping technique in smartpls 2.0 was performed.

\section{Findings}

\section{EFFECTS OF DEMOGRAPHIC CHARACTERISTICS}

As previously stated, the first aim of the research was to determine if the demographic characteristics (gender, marital status, age groups, educational status and income status) of shopping mall employees are significant on job satisfaction, managerial satisfaction and job turnover intention. Thus, in this part the findings related to demographic characteristics are displayed.

Table 3 shows the results of the comparison of the variables for gender. The findings display that gender is not a statistically significant variable for shopping mall employees on job satisfaction $(Z=$ $-0.623, p=0.533)$, managerial satisfaction $(Z=-0.401, p=0.688)$ and job turnover intention $(Z=-0.028, p=0.978)$.

Table 4 demonstrates the results of the comparison of the variables for marital status. The findings show that marital status is not a statistically significant variable for shopping mall employees on 
TABLE 3 Mann Whitney-U Test Results for Job Satisfaction, Managerial Satisfaction and job Turnover Intention between Female and Male

\begin{tabular}{lrrrrrr}
\hline Factors & $(1)$ & $(2)$ & $(3)$ & $(4)$ & $(5)$ & $(6)$ \\
\hline Job satisfaction & Female & 3.60 & 0.94 & MW-U & -0.623 & 0.533 \\
& Male & 3.71 & 0.86 & & & \\
\hline Managerial satisfaction & Female & 3.67 & 0.78 & MW-U & -0.401 & 0.688 \\
& Male & 3.67 & 0.87 & & & \\
\hline Job turnover intention & Female & 2.38 & 1.10 & MW-U & -0.028 & 0.978 \\
& Male & 2.40 & 1.12 & & & \\
\hline
\end{tabular}

NотеS Column headings are as follows: (1) gender, (2) mean, (3) standard deviation, (4) test type, (5) test value, (6) $p$.

TABLE 4 Mann Whitney-U Test Results for job Satisfaction, Managerial Satisfaction and Job Turnover Intention between Married and Single

\begin{tabular}{lrrrrrr}
\hline Factors & $(1)$ & $(2)$ & $(3)$ & $(4)$ & $(5)$ & $(6)$ \\
\hline Job satisfaction & Married & 3.62 & 0.93 & MW-U & -0.125 & 0.900 \\
& Single & 3.68 & 0.88 & & & \\
\hline Managerial satisfaction & Married & 3.69 & 0.89 & MW-U & -0.317 & 0.751 \\
& Single & 3.66 & 0.79 & & & \\
\hline Job turnover intention & Married & 2.39 & 1.13 & MW-U & -0.009 & 0.993 \\
& Single & 2.39 & 1.09 & & & \\
\hline
\end{tabular}

Notes Column headings are as follows: (1) marital status, (2) mean, (3) standard deviation, (4) test type, (5) test value, (6) $p$.

TABLE 5 Mann Whitney-U test Results for job Satisfaction, Managerial Satisfaction and Job Turnover Intention between Age Groups

\begin{tabular}{lrrrrrr}
\hline Factors & $(1)$ & $(2)$ & $(3)$ & $(4)$ & $(5)$ & $(6)$ \\
\hline Job satisfaction & $20-30$ & 3.63 & 0.87 & MW-U & -0.999 & 0.318 \\
& $31-40$ & 3.70 & 0.94 & & & \\
\hline Managerial satisfaction & $20-30$ & 3.55 & 0.86 & MW-U & -2.484 & 0.113 \\
& $31-40$ & 3.76 & 0.75 & & & \\
\hline Job turnover intention & $20-30$ & 2.46 & 1.14 & MW-U & -0.810 & 0.418 \\
& $31-40$ & 2.28 & 1.05 & & & \\
\hline
\end{tabular}

Notes Column headings are as follows: (1) age groups, (2) mean, (3) standard deviation, (4) test type, (5) test value, (6) $p$.

job satisfaction $(Z=-0.125, p=0.900)$, managerial satisfaction $(Z=$ $-0.317, p=0.751)$ and job turnover intention $(Z=-0.009, p=0.993)$.

In the table 5 , the results of the comparison of the variables for age groups are displayed. The findings show that age is not a statistically significant variable for shopping mall employees on job satisfaction $(Z=-0.999, p=0.318)$, managerial satisfaction $(Z=-2.484, p=0.113)$ and job turnover intention $(Z=-0.810, p=0.418)$. 
тAвLE 6 Kruskal Wallis-H Test Results for Job Satisfaction, Managerial Satisfaction and Job Turnover Intention among Educational Status

\begin{tabular}{llrrrrrr}
\hline Factors & $(1)$ & $(2)$ & $(3)$ & $(4)$ & $(5)$ & $(6)$ & $(7)$ \\
\hline Job & Primary & 3.23 & 0.90 & $\mathrm{Kw}-\mathrm{H}$ & 14.006 & 0.003 & $4>1$ \\
satisfaction & High school & 3.68 & 0.97 & & & & $3>1$ \\
& BA & 3.81 & 0.73 & & & & \\
& MA or PhD & 4.18 & 0.92 & & & & \\
\hline Managerial & Primary & 3.30 & 0.98 & $\mathrm{Kw}-\mathrm{H}$ & 15.747 & 0.001 & $4>1$ \\
satisfaction & High school & 3.69 & 0.75 & & & & $3>1$ \\
& BA & 3.77 & 0.76 & & & & $2>1$ \\
& MA or PhD & 4.37 & 0.44 & & & & \\
\hline Job turnover & Primary & 2.57 & 1.17 & $\mathrm{Kw}-\mathrm{H}$ & 5.896 & 0.117 & - \\
intention & High school & 2.47 & 1.06 & & & & \\
& BA & 2.33 & 1.11 & & & & \\
& MA or PhD & 1.63 & 0.86 & & & & \\
\hline
\end{tabular}

Notes Column headings are as follows: (1) educational status, (2) mean, (3) standard deviation, (4) test type, (5) test value, (6) $p$, (7) reason.

TABLE 7 Kruskal Wallis-H Test Results for Job Satisfaction, Managerial Satisfaction and Job Turnover Intention among Income Status

\begin{tabular}{llrrrrrr}
\hline Factors & $(1)$ & $(2)$ & $(3)$ & $(4)$ & $(5)$ & $(6)$ & $(7)$ \\
\hline Job & $0-1.300$ & 3.13 & 0.87 & $\mathrm{Kw}-\mathrm{H}$ & 24.956 & 0.000 & $3>1$ \\
satisfaction & $1.301-2.600$ & 3.77 & 0.74 & & & & $2>1$ \\
& $>2.601$ & 4.01 & 1.05 & & & & \\
\hline Managerial & $0-1.300$ & 3.15 & 0.85 & $\mathrm{Kw}-\mathrm{H}$ & 27.302 & 0.000 & $3>1$ \\
satisfaction & $1.301-2.600$ & 3.78 & 0.69 & & & & $2>1$ \\
& $>2.601$ & 4.06 & 0.85 & & & & \\
\hline Job turnover & $0-1.300$ & 2.88 & 1.12 & $\mathrm{KW}-\mathrm{H}$ & 19.011 & 0.000 & $3>2$ \\
intention & $1.301-2.600$ & 2.37 & 1.02 & & & & $3>1$ \\
& $>2.601$ & 1.77 & 1.02 & & & & $2>1$ \\
\hline
\end{tabular}

NотеS Column headings are as follows: (1) income status (Turkish Lira), (2) mean, (3) standard deviation, (4) test type, (5) test value, (6) $p$, (7) reason.

Table 6 shows the results of the comparison of the variables for educational status. The findings show that educational status affects job satisfaction $\left(\chi^{2}=14.006, p=0.003\right)$ and managerial satisfaction $\left(\chi^{2}=15.747, p=0.001\right)$, however, it does not affect job turnover intention $\left(\chi^{2}=5.896, p=0.117\right)$.

In the table 7 , the results of the comparison of the variables for income are shown. The findings show that income status affects job satisfaction $\left(\chi^{2}=24.956, p=0.000\right)$, managerial satisfaction $\left(\chi^{2}=\right.$ 27.302, $p=0.000)$ and job turnover intention $\left(\chi^{2}=19.011, p=0.000\right)$. 
TABLE 8 The Correlations among Variables

\begin{tabular}{|c|c|c|c|c|}
\hline \multicolumn{2}{|l|}{ Factors } & (1) & (2) & (3) \\
\hline \multicolumn{2}{|c|}{ (1) Job satisfaction } & $(0.952)$ & & \\
\hline \multicolumn{2}{|c|}{ (2) Managerial satisfaction } & $0.564^{* *}$ & $(0.940)$ & \\
\hline \multicolumn{2}{|c|}{ (3) Job turnover intention } & $-0.567^{* *}$ & $-0.445^{* *}$ & $(0.940)$ \\
\hline \multicolumn{5}{|c|}{ NOTES ${ }^{*} p<0.05 .{ }^{* *} p<0.01$} \\
\hline TABLE 9 Reliabi & icators & & & \\
\hline \multirow[t]{2}{*}{ Factors } & Items & Indicator Reliability & Internal C & Reliab. \\
\hline & & Outer Loadings & Composite & $\overline{\text { iability }}$ \\
\hline \multirow[t]{3}{*}{ Job turnover } & jt1 & 0.9079 & & 0.9577 \\
\hline & jt 2 & 0.9759 & & \\
\hline & jt 3 & 0.9759 & & \\
\hline \multirow[t]{5}{*}{ Job satisfaction } & js1 & 0.9385 & & 0.9637 \\
\hline & js 2 & 0.8616 & & \\
\hline & js 3 & 0.9430 & & \\
\hline & js 4 & 0.9390 & & \\
\hline & js 5 & 0.9022 & & \\
\hline \multirow{4}{*}{$\begin{array}{l}\text { Managerial } \\
\text { satisfaction }\end{array}$} & ms1 & 0.9121 & & 0.9679 \\
\hline & ms2 & 0.9331 & & \\
\hline & ms3 & 0.9261 & & \\
\hline & $\mathrm{ms} 4$ & 0.9162 & & \\
\hline
\end{tabular}

\section{CORRELATIONS AND MEDIATION ANALYSIS RESULTS}

Concerning the second aim of the research, it was to test if there is a significant relation among job satisfaction, managerial satisfaction and job turnover intention, and the third aim was to question whether the job satisfaction of shopping mall employees is the mediator on the relation between managerial satisfaction and job turnover intention. In this part, the results related to correlations and mediation analysis are explained.

Between job satisfaction and managerial satisfaction, a positive and significant relation $(r=0.564, p=0.000)$ was determined, thus, hypothesis 1 was confirmed. Between job satisfaction and job turnover intention, a negative and significant relation $(r=-0.567, p=$ o.ooo) was determined. So, hypothesis 2 was confirmed. Concerning another correlation, a negative and significant relation $(r=-0.445, p$ $=0.000$ ) between managerial satisfaction and job turnover intention was determined. Thus, hypothesis 3 was confirmed.

In order to perform the mediation analysis, the factors must be reliable and valid. For reliabilities, indicator and internal consistency 
TABLE 10 Validity Indicators

\begin{tabular}{lrrrrr}
\hline Factors & Conv. val. & \multicolumn{3}{c}{ Discriminant validity } \\
\cline { 2 - 4 } \cline { 5 - 6 } & AVE & & $(1)$ & $(2)$ & (3) \\
\hline (1) Job turnover & 0.8499 & & 0.9219 & & \\
(2) Job satisfaction & 0.8416 & & 0.5663 & 0.9173 & \\
(3) Managerial satisfaction & 0.9097 & & -0.3859 & -0.5534 & 0.9537 \\
\hline
\end{tabular}

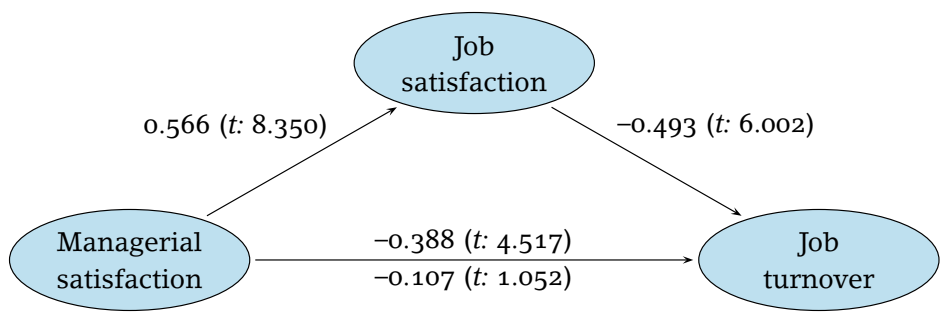

FIGURE 1 The Mediating Role of Job Satisfaction on the Relationship between Managerial Satisfaction and Job Turnover

reliability must be checked. Table 9 shows the reliability (results) of the indicators. For indicator reliability, outer loadings were examined and it was determined that each of the loading values was higher than 0.70 (Hulland 1999) and for internal consistency reliability, composite reliability values were examined and each of the factor values was higher than 0.70 (Bagozzi and Yi 1988). Following the analyses, it was determined that the factors were reliable.

For validity of the factors, convergent and discriminant validity results were checked (table 10). For convergent validity, AvE results were examined and each of them was seen to be higher than 0.50 (Bagozzi and Yi 1988); for discriminant validity, square root of AVE was calculated. Consequently, it was seen that the calculated values were higher than latent variable correlations (Fornell and Larcker 1981). Following the analyses, it was determined that the factors were valid.

In figure 1 , following the analysis made with smartpls ( 5.000 bootstrapping), it was determined that there was a significant and negative relation between managerial satisfaction and job turnover ($0.388, t=4.517)$. However, when the mediation of job satisfaction was integrated in this relation, it became possible to state that the relation between managerial satisfaction and job turnover became insignificant $(-0.107, t=1.052)$. The obtained result showed that job satisfaction fully mediated the relation between managerial satisfaction and job turnover. So, hypothesis 4 was confirmed.

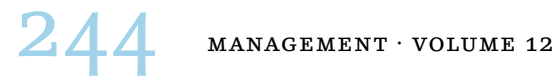


As previously emphasized in the literature, the view that the individuals leave their managers not their jobs is not supported as a result of the research made with the shopping mall employees in our sample. The reason why the shopping mall employees leave their jobs is not the managerial satisfaction, but the job satisfaction (0.566, $t=8.350$ ). The results showed that the higher job satisfaction decreases job turnover intention $(-0.493, t=6.002)$.

\section{Discussion}

The results of the research have shown that the relationship between managerial satisfaction and job satisfaction was similar with the results of the previous researches in the literature (Ellinger and Bostrom 1999; Ellinger, Ellinger and Keller 2003; Lok and Crawford 2004; Elloy 2006; Noelker et al. 2009; Keser 2011). The increase in the perceived positive attitudes of the managers affects the job satisfaction of the employees in the positive way. On the other hand, the relationship between job satisfaction and job turnover intention had similar results as in the previous researches in the literature (Crampton and Wagner 1994; Hanisch, Hulin, and Roznowski 1998; Truckenbrodt 2000; Lambert, Hogan, and Barton 2001; Luthans 2011). When the job satisfaction of the employees increases, their job turnover intention gets low. Lastly, it was also determined that the relationship between managerial satisfaction and job turnover intention was similar with the results of the previous researches in the literature (Khatri, Budhwar, and Fern 1999; Rhoades and Eisenberger 2002; Maertz et al. 2007; Alkahtani 2015). The increase in the perceived positive attitudes of the managers decreases the job turnover intention of the employees.

The most interesting result of the research was about the reason why the shopping mall employees leave their jobs. Accordingly, it is concluded that those with high levels of managerial satisfaction and job satisfaction were less likely to leave their jobs. Besides, managerial dissatisfaction was found to be related to a decrease in the perceptions of job satisfaction, which further would be related to job turnover intentions.

\section{Limitations and Future Research}

Within the context of the research, Spector's job satisfaction scale was planned to be used, however, as the scale form was quite long, it was not allowed to be used by the shopping mall managers. As a consequence, a shorter version of job satisfaction scale (Brayfield and Rothe 1951) was preferred. 
Although managerial satisfaction was determined as a processor reason for job turnover intention, further studies should examine the effect of other factors such as pay, promotion, nature of work, operating conditions on job turnover intention by using of a more detailed job satisfaction scale.

\section{References}

Alkahtani, A. H. 2015. 'Investigating Factors that Influence Employees' Turnover Intention: A Review of Existing Empirical Works.' International Journal of Business and Management 10 (12): 152-66.

Asiltürk, Ö. 2010. 'The Image of Shopping Centers, and an Application on Shopping Centers in Ankara.' Master dissertation, Gazi University, Ankara.

Bagozzi, R. P., and Y. Yi. 1988. 'On the Evaluation of Structural Equation Models.' Journal of the Academy of Marketing Science 16 (1): 74-94.

Başol, O. 2016. 'Classic or Modern? Enhancement of Job Satisfaction Scale for Green Job Workers.' Management 11 (2): 103-22.

Brayfield, A. H., and H. F. Rothe. 1951. 'An Index of Job Satisfaction.' Journal of Applied Psychology 35 (5): 307-11.

Brown, S. P., and R. A. Peterson. 1993. 'Antecedents and Consequences of Salesperson Job Satisfaction: Meta-Analysis and Assessment of Causal Effects.' Journal of Marketing Research 30 (1): 63-77.

Cammann, C. F., M. D. Jenkins, and J. Klesh. 1979. 'The Michigan Organizational Assessment Questionnaire.' Unpublished Manuscript, University of Michigan, Ann Arbor, MI.

Crampton, S. M., and J. A. Wagner. 1994. 'Percept-percept Inflation in Micro Organizational Research: An Investigation of Prevalence and Effect.' Journal of Applied Psychology 79 (1): 67-76.

Duffy, M. K., J. D. Shaw, K. L. Scott, and B. J. Tepper. 2006. 'The Moderating Roles of Self-Esteem and Neuroticism in the Relationship between Group and Individual Undermining Behavior.' Journal of Applied Psychology 91:1066-77.

Dülgeroğlu, İ., and Ç. Taşkin. 2015. 'Internal Marketing in Public Service Sector and its Effect on Job Satisfaction.' Electronic Journal of Vocational Colleges 5 (2): 1-6.

Ellinger, A. D., and R. P. Bostrom. 1999. 'Managerial Coaching Behaviors in Learning Organizations.' Journal of Management Development 18 (9): 752-71.

Ellinger, A. D., A. E. Ellinger, and S. B. Keller. 2003. 'Supervisory Coaching Behavior, Employee Satisfaction, and Warehouse Employee Performance: A Dyadic Perspective in the Distribution Industry.' $\mathrm{Hu}$ man Resource Development Quarterly 14 (4): 435-58.

Elloy, D. F. 2006. 'Superleader Behaviors and Self-Managed Work Teams: Perceptions of Supervisory Behaviors, Satisfaction with Growth,

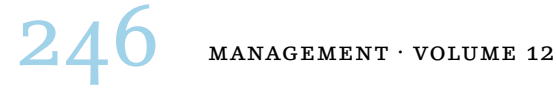


and Team Functions.' Journal of Business \& Economics Research 4 (12): 97-102.

Fornell, C., and D. F. Larcker. 1981. 'Evaluating Structural Equation Models with Unobservable Variables and Measurement Error.' Journal of Marketing Research 18 (1): 39-50.

Friday, S. S., and E. Friday. 2003. 'Racioethnic Perceptions of Job Characteristics and Job Satisfaction.' Journal of Management Development $22(5): 426-42$.

Hanisch, K. A., C. L. Hulin, and M. Roznowski. 1998. 'The Importance of Individuals' Repertoires of Behaviors: The Scientific Appropriateness of Studying Multiple Behaviours and General Attitudes.' Journal of Organizational Behavior 19 (5): 463-80.

Hulland, J. 1999. 'Use of Partial Least Squares (PLS) in Strategic Management Research: A Review of Four Recent Studies.' Strategic Management Journal 20 (2): 195-204.

Karatuna, I., and O. Başol. 2017. 'Job Satisfaction of Part-Time vs. FullTime Workers in Turkey: The Effect of Income and Work Status Satisfaction.' International Journal of Value Chain Management 8 (1): 5872.

Keser, A. 2006. 'Çağrı Merkezi Çalışanlarında İş Yükü Düzeyi ile İş Doyumu İlişkisinin Araştırılması.' Kocaeli Üniversitesi Sosyal Bilimler Enstitüsü Dergisi 11 (1): 100-19.

2011. Çalışma Psikolojisi. Bursa: Ekin Yayınevi.

Khatri, N., P. Budhwar, and C. T. Fern. 1999. 'Employee Turnover: Bad Attitude or Poor Management.' http://cyb.ox.or.kr/lms_board/bbs _upload/\%Co\%CC\%C1\%F7\%Co\%C7\%B5\%B53.pdf

Lambert, E. G., N. L. Hogan, and S. M. Barton. 2001. 'The Impact of Job Satisfaction on Turnover Intent.' The Social Science Journal 38 (2): 233-50.

Locke, E. A. 1976. 'The Nature and Causes of Job Satisfaction.' In Handbook of Industrial and Organizational Psychology, edited by M. D. Dunnette, 1297-349. Chicago: Rand McNally.

Lok, P., and J. Crawford. 2004. 'The Effect of Organisational Culture and Leadership Style on Job Satisfaction and Organisational Commitment: A Cross-National Comparison.' Journal of Management Development 23 (4): 321-38.

Luthans, F. 2011. Organizational Behavior: An Evidence-Based Approach. 12th Ed. New York: McGraw-Hill Irwin.

Maertz, C. P., R. W. Griffeth, N. S. Campbell, and D. G. Allen. 2007. 'The Effects of Perceived Organizational Support and Perceived Supervisor Support on Employee Turnover.' Journal of Organizational Behavior 28 (8): 1059-75.

McNatt, D. B., and T. A. Judge. 2008. 'Self-efficacy Intervention, Job Attitudes, and Turnover: A Field Experiment with Employees in Role Transition.' Human Relations 61:783-810. 
Noelker, L., F. Ejaz, H. Menne, and J. Bagakas. 2009. 'Factors Affecting Frontline Workers' Satisfaction with Supervision.' Journal of Aging and Health 21 (1): 85-101.

Rhoades, L., and R. Eisenberger. 2002. 'Perceived Organizational Support: A Review of the Literature.' Journal of Applied Psychology 87 (4): 698-714.

Silah, M. 2005. Endüstride Çalşıma Psikolojisi. Ankara: Seçkin Kitabevi.

Spector, P. E. 1985. 'Measurement of Human Service Staff Satisfaction: Development of the Job Satisfaction Survey.' American Journal of Community Psychology 13 (6): 693-713.

- 1997. Job Satisfaction: Application, Assessment, Causes, and Consequences. London: Sage.

Stajkovic, A. D., and F. Luthans. 1998. 'Self-efficacy and Work-related Performance: A Meta-Analysis.' Psychological Bulletin 124 (2): 24061.

Tett, R. P., and J. P. Meyer. 1993. 'Job Satisfaction, Organizational Commitment, Turnover Intention and Turnover: Path Analyses Based on Meta-Analytic Findings.' Personnel Psychology 46 (2): 259-93.

Truckenbrodt, Y. B. 2000. 'The Relationship between Leader-Member Exchange and Commitment and Organizational Citizenship Behavior.' Acquisition Review Quarterly 7 (3): 233-44.

This paper is published under the terms of the Attribution-

NonCommercial-NoDerivatives 4.o International (CC BY-NC-ND 4.0)

License (http://creativecommons.org/licenses/by-nc-nd/4.o/). 